\title{
Zooplankton of Sarikamish Lake (Uzbekistan)
}

\author{
X. X. Abdinazarov ${ }^{1}$, M. J. Madumarov' ${ }^{1}$, S. M. Haydarov² \\ ${ }^{1}$ Kukan State Pedagogical Institute, Kokand, Uzbekistan \\ ${ }^{2}$ Tashkent State Agrar University, Tashkent, Uzbekistan \\ Email: ozodbek88@bk.ru
}

How to cite this paper: Abdinazarov, X.X., Madumarov, M.J. and Haydarov, S.M. (2019) Zooplankton of Sarikamish Lake (Uzbekistan). Open Access Library Journal, 6: e5288.

https://doi.org/10.4236/oalib.1105288

Received: February 25, 2019

Accepted: March 24, 2019

Published: March 27, 2019

Copyright $\odot 2019$ by author(s) and Open Access Library Inc.

This work is licensed under the Creative Commons Attribution International License (CC BY 4.0).

http://creativecommons.org/licenses/by/4.0/

\begin{abstract}
The total of 35 species of zooplankton organisms were found on the Sarikamish lake, 17 of which were armor, 10 species of cladocers and 8 species of copra. New 7 species of Lecane punctate, Lecane stenosis, Colurella adriatica, Colurella obtusa, Lepadella ehrenbergi were found to be new to Fergana valley (Uzbekistan).
\end{abstract}

\section{Subject Areas}

Biochemistry, Biodiversity

\section{Keywords}

Fergana Valley, Sarikamishlake, Zooplankton, Species, Quality, Quantitative

\section{Introduction}

At present, the country pays special attention to the development of fishing industry, increasing the production of fishery network management system, providing the population with quality fish and fish products. The Resolution of the President of the Republic of Uzbekistan dated May 1, 2017 "On Measures to Improve the Fisheries Management System", Resolution of the Cabinet of Ministers of the Republic of Uzbekistan №719 of September 13, 2017 “On Measures for Complex Integrated Fisheries Development” №845 October 18, 2017 “On Measures for Strengthening the Livelihoods of Livestock Breeding and Fishery Sectors" and other regulatory legal acts related to this activity of a certain level of service [1] [2] [3].

In the field of hydrobiological investigations scientists of our country A.M. Mukhamediev, E.A. Toshpo'latov, I.M. Mirabdullaev, A.R. Kuzmetov, X.X. Abdinazarov, V.G. Kamilov, M.A. Yuldashov made scientific researches. Research on the taxonomy, distribution, ecological features of the zooplankton organisms on the various ecosystems and the increase in the productivity of fishing waters 
of the fishing grounds contributes to the implementation of the above mentioned decisions [4]-[10].

According to the rules for the collection of hydrobiological samples, the zooplankton samples are collected in two ways, in particular: 1) samples of quality; 2) quantity samples. To investigate Zooplankton's organisms, first, the location of the water basin has been determined. Then it was determined at which point water zooplankton organisms were more likely to get water and sample from here. Then, water entrances and outlets were identified in the water basin and observation points were identified. In the study, first of all, the temperature, clarity, $\mathrm{pH}$ and oxygen content of water were detected [11] [12].

There are about 30 natural lakes in the Fergana valley. These differences, such as, their size, depth, chemical composition of water, oxygen content, temperature, and location in the climate zone and so on, are determined by the composition of zooplankton and the number of organisms.

Under the influence of anthropogenic factors, the area is very short, and most of the lakes are filled with water and spring water. The area is also very small, with a range of 1.5 to 3 hectares (For example, Sarikamish, Abdusamat, Tuda, Kolgandarya and others) (Figure 1). The water of some lakes is poured directly into Syrdarya. The deepest lake is 3 - 4 meters above sea level. Mainly, it is covered with reed and cabbage plants. Because of the similar nature of these lakes, the zooplankton organs differ little from each other [6] [8].

Lake Sarikamish is located in the western part of the Ferghana Valley, one of the largest lakes in the valley, surrounded by the Syrdaryain the north and west, with its shallows in the southern and eastern part. It is located on the left bank of the Syrdarya. The average area of 800 - 900 hectares with an aquifer of $400-450$ hectares is $3 \mathrm{~m}$, and the maximum depth is $5 \mathrm{~m}$, which is in the group of shallow lakes according to these figures [8].

\section{Result and Discussion}

In 2012-2018 seasonal quality samples from these zooplankton species have been

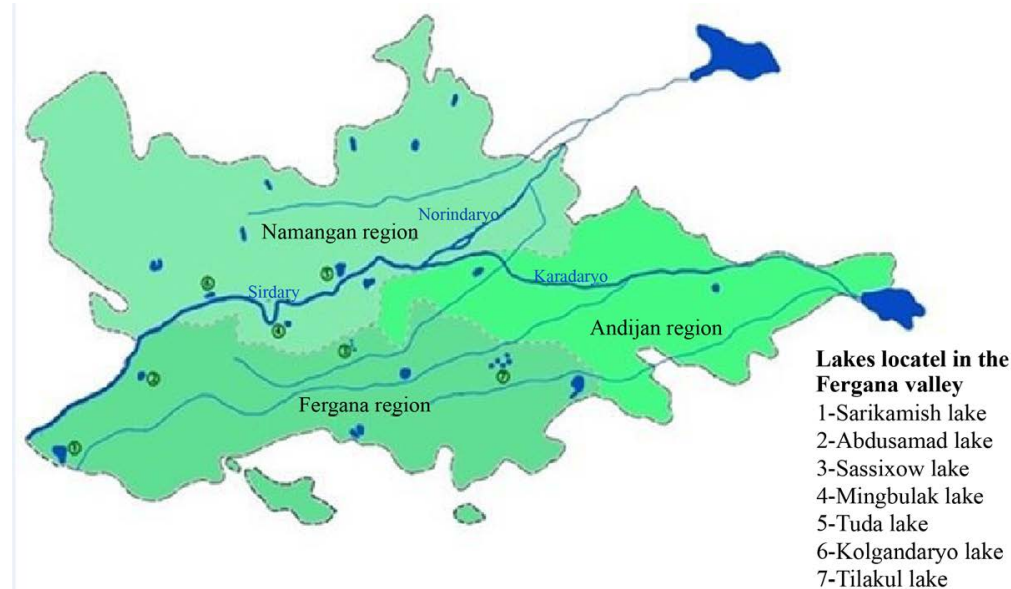

Figure 1. Landfill dams and lakes in the foothills Ferghana Valley. 
obtained. On average, 28 species of zooplankton organisms were identified. The lack of flow is due to the general features of layering the water level from the surface to the bottom, depending on the temperature, gas state and chemical composition [13] [14] [15].

In contrast to the rheophilic fauna of lakes and other stagnant water bodies, rivers and rivers, lymph nodes are called lamnophils. The zooplankton of the lake is considerably richer with regard to the organisms than rivers and reservoirs [5] [7] [8]. The zooplankton organisms contain a well-watered layer of water, which is rich in fauna, and provides favorable conditions for the development of phytoplankton and bacteria, which is a nutritious base for zooplankton organisms. Conditions for nutrition in oligotrophous lakes are high in their upper layers, and in the ewtrop lakes, rich in nutrients [8].

Favorable conditions for the development of zooplankton organisms are created in the shallow-litoral zone of the well-lit, well-ventilated, lush green vegetation. The number and composition of crustaceans are slightly higher than that of the lake's pelagial region, with the presence of Ceriodaphnia, Pokyphemus generation from the shoreline and hawthorn formations, as well as the presence of a large number of Chydoridae and Macrothricidae family members, phytophiles Simocephalus vetulus O.F Muller, Sida crystallina and can be found.

In the lake, one of the plankton forms is replaced by the year, with seasonal dynamics of the development of zooplankton organisms. In spring, the number of colovators will increase not only in the annual complex, but also in the warmth of Trichocerca, Synchaeta, Polyartra, Asplanchna, Lecane, Euchlanis, Keratella and other generations. In the summer, a group of horned crustaceans develops well.

Among the most common species are Asplanchnapriodonta, Keratella tropica, Keratella quadrata, Brachionus calyciflorus, Diaphanosoma mongolianum, Bosmina longirostris, Moina micrura, Cyclops vicinus, Lecane punctata, Thermocyclops vermifer and Phyllodiaptomusblanci.

As a result of the Sarikamish lake research, the variation of zooplankton species and their quantitative dynamics for the seasons has been monitored from April to October 2012-2018 years. A total of 35 species of plankton organisms were identified, 17 of which were Rotifera, 10 Cladocera and 8 Sopepoda (Table 1).

As a whole, the lake is the serum of the zooplankton, and in its summer season its quantitative indicator is 230 - 311 thousand $\mathrm{per} / \mathrm{m}^{3}$, and biomass - up to $3.12-3.85 \mathrm{~g} / \mathrm{m}^{3}$. The maximum development of Zooplankton corresponds to the summer months (Figure 2).

Here is a brief explanation of the representatives of zooplankton organisms that have been identified as a new species for the Ferghana Valley:

Colurellaadriatica (Ehrenberg, 1831) (Figure 3(1)): L = $90-100 \mathrm{mkm}$, length-40 - $50 \mathrm{mkm}$. The pantsir sank into the lateral force (flattened). She has a hole. The next edge of the pantsir is extended to two sharp thorns. The elbow is in the form of a large triangle on the last edge. Leg cuffs are compacted with one another, their length is $35-40 \mathrm{mc}$. It was found in the border zone of Sarikamish Lake. 
Table 1. Quality composition and quantitative development of zooplankton of Sarikamish lake.

\begin{tabular}{|c|c|c|c|c|c|c|c|c|}
\hline \multirow{2}{*}{ № } & \multirow{2}{*}{ Species } & \multicolumn{7}{|c|}{ Months } \\
\hline & & IV & $\mathrm{V}$ & VI & VII & VIII & IX & $\mathrm{X}$ \\
\hline \multicolumn{9}{|c|}{ ROTIFERA } \\
\hline 1. & Asplanchna sieboldi & - & + & + & + & + & + & + \\
\hline 2. & Filinia longiseta & - & + & + & + & - & - & - \\
\hline 3. & Keratella quadrata & + & + & - & - & - & - & + \\
\hline 4. & K. cochlearis & - & + & + & + & + & + & - \\
\hline 5. & K. tropica & - & + & + & + & + & + & - \\
\hline 6. & Brachionus angularis & - & + & + & + & - & + & - \\
\hline 7. & B. calyciflorus & - & + & + & + & + & - & - \\
\hline 8. & Notholca acuminate & + & - & - & - & - & - & - \\
\hline 9. & Lecane luna & - & + & - & + & + & + & - \\
\hline 10. & L. bulla & - & + & + & + & - & - & - \\
\hline 11. & L. quadridentata & - & + & - & - & - & & - \\
\hline 12. & L. decipiens & - & + & + & - & - & - & - \\
\hline 13. & Macrochaetusaltamirai & - & - & + & + & - & - & - \\
\hline 14. & Euchlanis dilatata & + & + & + & + & + & + & + \\
\hline 15. & Lophocharisturanicus & - & + & - & - & - & - & - \\
\hline 16. & Polyarthra vulgaris & + & + & + & + & + & + & + \\
\hline 17. & Synchaeta sp. & + & - & + & - & + & + & - \\
\hline \multicolumn{9}{|c|}{ CLADOCERA } \\
\hline 18. & Bosmina longirostris & + & + & + & + & + & + & + \\
\hline 19. & Daphnia cf. galeata & + & + & + & + & + & + & + \\
\hline 20. & Ceriodaphnia turkestanica & & + & + & + & + & + & + \\
\hline 21. & Simocephalus vetulus & + & + & + & - & - & - & + \\
\hline 22. & Moina micrura & - & + & + & + & + & + & + \\
\hline 23. & Scapholeberis kingi & - & - & + & + & + & + & - \\
\hline 24. & Alona rectangular & + & + & + & - & + & + & - \\
\hline 25. & Chydorus sphaerius & + & + & + & + & + & + & + \\
\hline 26. & Lepadella ehrenbergii Perti ${ }^{*}$ & + & - & - & - & - & + & - \\
\hline 27. & Pleuroxus aduncus & + & + & + & + & - & - & + \\
\hline \multicolumn{9}{|c|}{ COPEPODA } \\
\hline 28. & Eucyclops serrulatus & + & + & + & + & + & + & + \\
\hline 29. & Cyclops vicinus & + & - & - & - & - & - & + \\
\hline 30. & Megacyclops viridis & + & - & - & - & + & - & - \\
\hline 31. & Microcyclops pachyspina & - & + & + & + & + & + & - \\
\hline 32. & Thermocyclops vermifer & + & + & + & + & + & + & + \\
\hline
\end{tabular}




\section{Continued}

\begin{tabular}{|c|c|c|c|c|c|c|c|c|}
\hline 33. & T. dybowskii & + & - & - & - & - & - & - \\
\hline 34. & Mesocyclops ogunnus & - & + & + & + & + & + & + \\
\hline \multirow[t]{2}{*}{35.} & Acanthodiaptomus denticornis & + & + & + & + & + & + & + \\
\hline & Total species & 18 & 27 & 26 & 23 & 21 & 21 & 16 \\
\hline \multicolumn{2}{|c|}{ Amount of measure (thousand per $/ \mathrm{m}^{3}$ ) } & 34 & 111 & 230 & 310 & 197 & 179 & 133 \\
\hline & Biomass, $\mathrm{g} / \mathrm{m}^{3}$ & 0.34 & 1.99 & 2.66 & 3.12 & 3.85 & 2.99 & 1.08 \\
\hline
\end{tabular}

\section{Sarikamish lake}

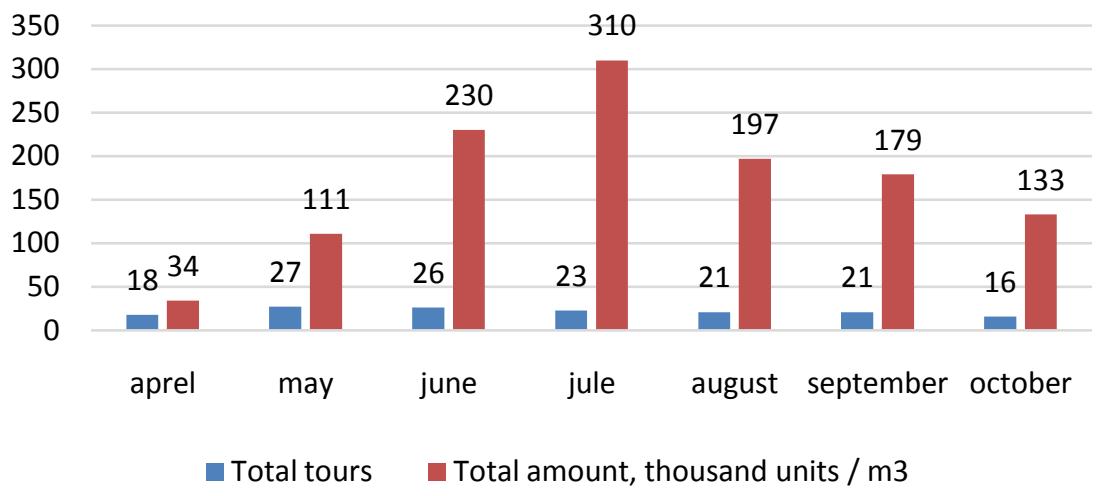

(a)

\section{Sarikamish lake}

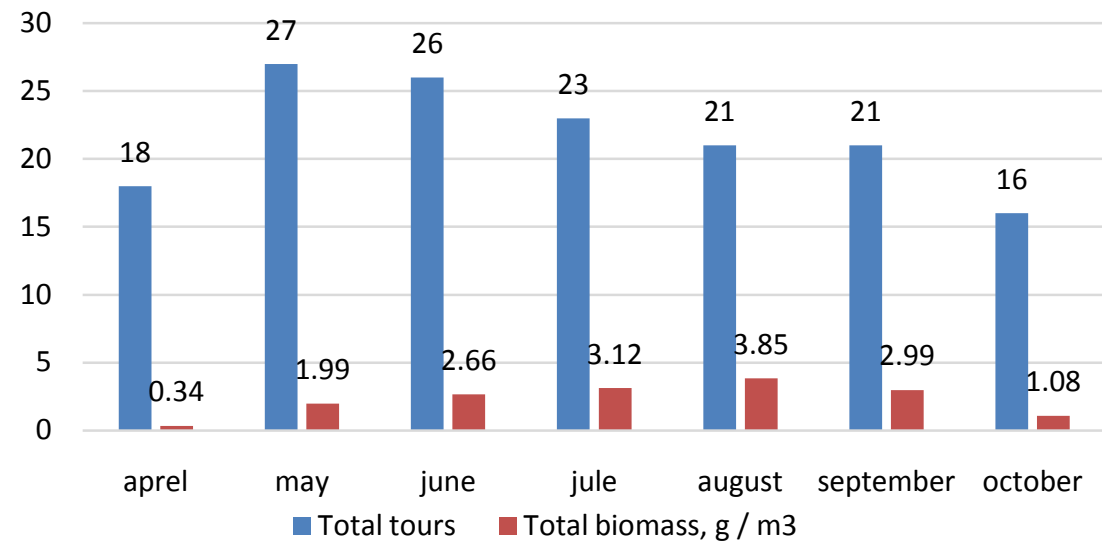

(b)

Figure 2. Water bodies of the Fergana valley are zooplankton organisms (a) Amount of measure (thousand per $/ \mathrm{m}^{3}$ ), (b) Biomass $\left(\mathrm{g} / \mathrm{m}^{3}\right)$.

Lecane stenosis (Meisner, 1908) (Figure 3(2)): L = $100-110 \mathrm{mcm}, \mathrm{W}=90$ $95 \mathrm{mcm}$. Pantsir is elliptic. The side teeth in the front of the pantsir are short and intrinsically oriented. The backplane is wide, with no difficulty at the back. The first leg of the foot is oval, barely visible. The second is heavy, romantic. The base of the toes is expanded, the length is $45-50 \mathrm{~m}$, and the width is $7-8 \mathrm{mkm}$. It was found in the border zone of Sarikamish Lake. 


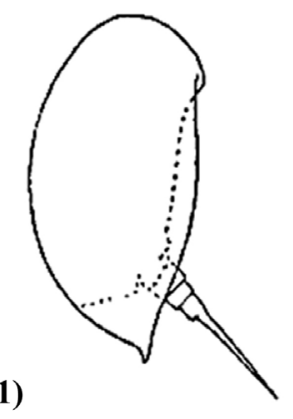

1)

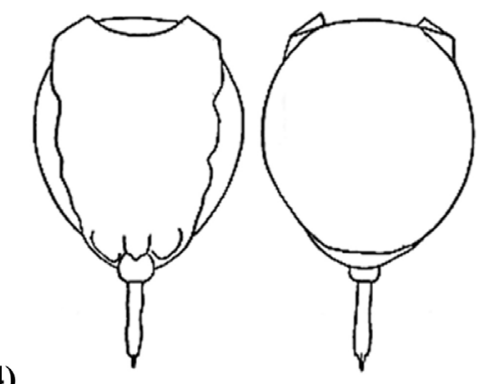

4)
2)

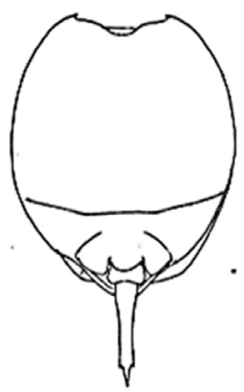

3)

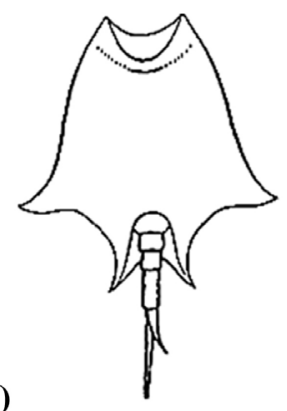

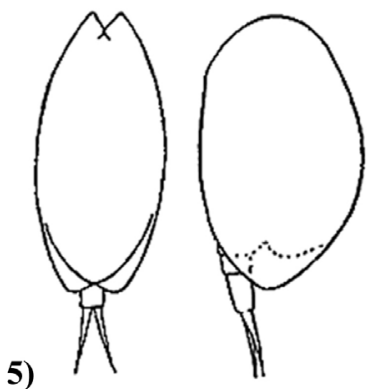

Figure 3. 1-Colurellaadriatica; 2-Lecanestenroosi; 3-Lepadellaehrenbergii; 4-Lecanepunctata; 5-Colurella obtusa.

Lepadellaehrenbergii (Perti, 1850) (Figure 3): $\mathrm{L}=80-90 \mathrm{mc}, \mathrm{W}=80-85$ $\mathrm{mcm}$. The pantsir is in the wrong angle. The lateral and lateral edges of the boat are sharp, upwards slightly bent in the form of rings. The front edges of the pantsir are semi-miraculous, and the abdomen is relatively deep. At the end of the pantsir, there are sharp corners that are separated from the edge. His legs are three saddles. His fingers are sharp, not long. The length of the finger is $28-30$ $\mathrm{mc}$, the smallest is $22-25 \mathrm{mkm}$. It was found in the border zone of Sarikamish Lake.

Lecane punctata (Murray, 1913) (Figure 3(4)): $\mathrm{L}=80-90 ; \mathrm{W}=70-72$. The pantsir's front shoulder is a weak bubble and the abdomen pantser is weak. The three sides of the pantsir are covered with sculpture dots. The abdomen plate is significantly narrower than the shoulder plate and is not wounded. The next signing was smaller and round, with the other side of the pants. The first leg of the foot is large and uncertain; the other is large and round. The end of the finger is wider, with a length of $32-33$ microns, a nail length of $6 \mathrm{mkm}$. It was found in the border zone of Sarikamish Lake.

Lecane punctata (Murray, 1913) (Figure 3(4)): $\mathrm{L}=80$ - 90; $\mathrm{W}=70-72$. The pantsir's front shoulder is a weak bubble, and the abdomen pantser is weak. The three sides of the pantsir are covered with sculpture dots. The abdomen plate is significantly narrower than the shoulder plate and is not wounded. The next signing was smaller and round, with the other side of the pants. The first leg of the foot is large and uncertain; the other is large and round. The end of the finger is wider, with a length of $32-33$ microns, a nail length of $6 \mathrm{mkm}$. It was found in the border zone of Sarikamish Lake. 
Colurella obtusa (Gosse, 1886) (Figure 3(5)): L $=64-66 \mathrm{mc}, \mathrm{W}=30-33 \mathrm{mcm}$. The pancreas is smooth glad, almost ovarian, slightly swollen on its side. The next edge has a slightly longer shoulder blade. Leg cuffs are sharp, relatively short. It was found in the border zone of Sarikamish Lake.

\section{Conclusion}

Totally, 35 species of zooplankton organisms were detected in Sarikamish Lake, 17 of which were locomotives, 10 cladocers and 8 cogododes. New 5 species of Lecane punctate, Lecane stenroosi, Colurella adriatica, Colurella obtusa, and Lepadella ehrenbergi were found to be new to Fergana valley.

\section{Conflicts of Interest}

The authors declare no conflicts of interest regarding the publication of this paper.

\section{References}

[1] Resolution of the President of the Republic of Uzbekistan from May 1, 2017 "On Measures to Improve the Fishery Management System” No. 2939.

[2] Resolution of the Cabinet of Ministers of the Republic of Uzbekistan No. 719 of September 13, 2017 "On Measures for Comprehensive Development of the Fishery Sector".

[3] Resolution of the Cabinet of Ministers of the Republic of Uzbekistan dated October 18, 2017 "On Measures to Strengthen the Livelihoods of Livestock and Fishery Sectors".

[4] Mukhamediev, A.M. (1967) Hydrobiology of Water Bodies of the Fergana Valley. Fan, Tashkent, 275.

[5] Tashpulatov, E.A. (1975) Hydrobiology of Reservoirs in the Western Part of the Fergana Valley. Tashkent, 24.

[6] Mirabdullaev, I.M., Abdurahimova, A.N., Kuzmetov, A.R. and Abdinazarov, Kh.H. (2012) Crystacea and Copepoda of Uzbekistan. Toshkent, 98.

[7] Kuzmetov, A.R. (1999) Zooplankton of Fish Ponds of Uzbekistan. From Ru AS, Tashkent, 16.

[8] Abdinazarov, X.X. (2018) Zoooplankton of the Fergana Valley Watersheds. Tashkent, 18.

[9] Kamilov, V.G. (2019) Features of Reproductive Biology of Fish Species Cultivated in Uzbekistan. Tashkent, 31.

[10] Yuldashov, M.A. (2019) Biological Bases of Increasing Fish Productivity in Various Water Reservoirs in Uzbekistan. Tashkent, 28.

[11] Mustafaeva, Z.A., Mirzaev, U.T. and Kamilov, B.G. (2017) Metodyhydrobial Equipment Monitoring Monitoring Objects in Uzbekistan. Tashkent, 34-49.

[12] Kartasheva, N.V., Isakova, E.F. and Nedosekin, A.G. (2006) Zooplankton. In: Practical Hydrobiology. Freshwater Ecosystems, Publishing House of Moscow State University, Moscow, 165-245.

[13] Kuzmetov, A.R. and Abdinazarov, X.X. (2016) Ecological-Fantic Characteristic of Reservoirs Zooplankton in Uzbekistan. European Journal of Technical Natural Sciences, No. 1-2, 3-6. 
[14] Kuzmetov, A.R., Mustafayeva, Z.A., Abdinazarov, Kh.H. and Sadikova, S.A. (2016) Zooplankton of Uzbekistan's Reservoirs. Continental Aquaculture: A Response to the Challenges of Time. Materials of the All-Russian Scientific-Practical Conference, Moscow, No. 2, 121-126.

[15] Kuzmetov, A.R. and Abdinazarov, Kh.H. (2017) Seasonal Succession of the Qualitative Composition of Zooplankton in Uzbekistan's Reservoirs. Path of Science International Journal of Science, No. 3, 27-29. 